\title{
Linguistic features of a politically correct English language discourse
}

\author{
Kseniya Melnikova ${ }^{1 *}$, and Alla Guslyakova ${ }^{2}$ \\ ${ }^{1}$ Yaroslavl State Technical University, 88 Moscow Avenue, Yaroslavl, 150023, Russian Federation \\ ${ }^{2}$ RUDN University, 6 Miklukho- Maklaya St, Moscow, 117198, Moscow Pedagogical State \\ University, 1/1 Malaya Pirogovskaya Str., Moscow, 119991, Russian Federation
}

\begin{abstract}
The problem of the research is the insufficient study of political correctness (PC) in the intercultural and linguistic aspects, as well as the urgent need to establish its status in the modern integrated culture. The relevance of the study is due to there is no unified approach to the analysis of the concept of PC in the political sphere. There is a special ideological cultural and behavioural linguistic tolerant tendency on the contrary to expressions subjected to public ostracism because the speeches of public figures contain too many politically incorrect statements. Thus, the "listener" may have an internal protest against the use of PC vocabulary in everyday life, although its use is forced upon society by all types of media. The study is touch upon the analysis of the vast corpus of statements by US President D. Trump on Twitter, as well as other open Internet sources. The problem of studying PC was dealt with as Russian scientists, such as A.B. Ostroukh, M. Yu. Palazhchenko, Yu.L. Gumanova, S.G. Ter - Minasova, L.V. Tsurikova and others, as well as their foreign colleagues: Paul Berman, Deborah Cameron and others. The research aims to attempt to describe the PC category in terms of cultural, behavioural and linguistic perspectives. By the tasks set for the study, the following methods were used: descriptive method, methods of distributive, component, quantitative and comparative analysis. The results could be used in educational and methodological activities as well as preparation of materials on cultural linguistics, lexicology, linguistic stylistics submissions, etc. The further research course plans to establish the relationship between the occasional euphemistic vocabulary.
\end{abstract}

\section{Introduction}

The phenomenon of political correctness (PC) attracts widely general attention and may be of value for society as a whole. In Western countries and in the United States of America non-using PC vocabulary is considered almost as a bad tone. But, on the other hand, the USA was led by Donald Trump, whose linguistic behaviour went openly against the PC culture.

The relevance of the study is considered in terms of the modern political situation, where the issue of tolerance in the context of international relations is especially acute and

\footnotetext{
* Corresponding author: ledeja@yandex.ru
} 
the insufficiently studied phenomenon of PC causes extreme interest to this particular problem. And, although the PC is quite a widespread phenomenon, it hasn't gained a better understanding of linguistic research yet. The PC problem was dealt with as Russian linguists, such as A.B. Ostroukh, M.Yu. Palazhchenko, Yu.L. Gumanova, S.G. Ter Minasova, L.V. Tsurikova and others, as well as their foreign colleagues: Paul Berman, Deborah Cameron and others.

\section{Problem Statement and Research Methods}

The research aims to study the linguistic expression of the PC in the political discourse of European countries and the United States of America. The object of the study is the PC statements of US President Donald Trump on Twitter and in other open Internet sources. Hence, we are going to analyze the PC phenomenon and its expression in a political discourse.

It is already obvious that nowadays there is an integration of humanitarian and social sciences in solving various linguistic problems. This way, it is hard to deny that the PC is already the cornerstone of such sciences as Linguistics, Sociology, Political science and Economics [1]. Also, it is already impossible to be sure exactly where the brinks of one science are the beginning of another one is. This intensive scientific development allows us to talk about cognitive science, namely Cognitive Linguistics. At the same time, such fundamental sciences as Philosophy, Psychology, Mathematics, Linguistics are combined with new developing sciences (Neurosciences, Computer science theory, Methods of Mathematical modelling and all of them use a cognitive approach in many ways [2].In terms of it, language is defined as a phenomenon of a cognitive-procedural nature and transmits information about the world, comprehensively processes this information and directly correlates with its construction and further classification. And it is the discourse that provides communication processes during which information is exchanged.

In order to better understand and analyze the cognitive and linguistic nature of political correctness this study uses the following methods: continuous sampling, stylistic, translation and a comparative analysis. The very importance of the research is in the fact that the study of PC is an important contribution to the phenomenon of "dialogue of cultures". The researching outcomes could be useful in the process of educational and methodological activities as well as preparation of materials on cultural linguistics, lexicology, regional studies, linguistic stylistics submissions, etc. The further research course plans to establish the relationship between the occasional euphemistic vocabulary and the theory of PC.

\section{Research Questions}

The very attention is devoted to studying the PC discourse and discourse analysis. By the researches of modern scientists, discourse isn't the only important form of the routine of human's life but the scope of extralinguistic factors necessary to understand the text [3]. The multidisciplinary study of discourse activates not only the intensification of scientific activity in this area but also contributes to the emergence of its new types [4]. By the other opinion, discourse considered as a related sequence of statements both semantically and grammatically intended to the reader, listener or observer, integrated communication and speech situation could be reflected along with the quality of non-linguistic factors [5].

The term "political correctness" is regularly used in the political vocabulary of the modern West. As a term, it was firstly proposed by the President of the American National Organization for Women's Rights Caren de Crow in 1983. The level of political correctness 
as a system of views began to expand, especially in colleges. The Oxford dictionary of new words defines political correctness as "conformity to a liberal or radical point of view on social and other issues, characterized by the protection of behaviour considered offensive and discriminative". PC is a cultural and behavioural and linguistic trend aimed to replace established terms that could hurt the feelings and dignity of an individual with emotionally neutral and/or positive euphemisms. Further, political correctness as a system of views began to spread mainly in higher educational institutions in the United States and then in other areas of American society [6].

\section{Purpose of the Study}

The United States is considered the birthplace of the PC concept. It appears in the fourth quarter of the XX century: the time when women, African-Americans and Spanishspeaking residents of the country gained access to education. The government began to make attempts to revise educational plans and introduce correct speech corrections. In the mid-70s of the last century, a law called The Sex Discrimination Act decided to replace the term "dustmen"(garbage collector) with "refuse collectors" in all media offering work. This period of US history is often characterized as the era of "verbal uplift". The issues of modern terminology attracted the closest public attention and political correctness gained both a huge number of supporters and opponents.

The long struggle for the rights of black Americans has produced concrete results. They achieved social equality and there was a strong need to replace words that carry a negative meaning. In the 60s of the XX century, the word "Negro" was replaced, due to associations with slavery, by the term "black". Subsequently, it became opposed to white and for greater political correctness the word "African-American" was adopted because it emphasizes the relation of black Americans with their motherland. There was a change of speech turnover Red Indians to Native Americans. With the advent of the concept of sexism, many language units fall into the category of sexist, and especially those that include the root "man" and the suffix -ess. The word "woman" feminists are alarmed by the root "man", since it is derived from man, and this is nothing more than a confirmation of male superiority. Feminists are willing to accept the existence of the word "woman" only as of the main lexeme and not a derivative of man; in this case, the man should be called not as before, but in a new way - "non - woman". Using the term "non-woman" concerning "men" thus moves them out of the language centre. The word "woman" is alternatively "wofem", "womban","woperson", "person of gender"; and for the plural word - "wimmin", "wimyn", "womyn". The point is without changing the ordinary sound of "woman" and "women", change their spelling, so that when reading it, you would not see their obvious "sexist" origin. So in the case of "wofem", it was decided to change the "male" unit of man to "female", like female and feminine. As for "womban", it was formed from the medical term "womb", which is understood as the female reproductive organ. The advantage of the expression "person of gender" which is an exception is that neither its pronunciation nor spelling does not mention "woman", the "minus" is considered to be its non-compactness.

In English, there is a type of discrimination called "ableism" (systemic discrimination against people with chronic diseases and disabilities). People with certain physical disabilities are not able to fully realize their talents due to biases related to their characteristics. The prefix challenged in English forms politically correct phrases. This prefix is used to replace such non-politically correct phrases, for example, "handicapped" or "disabled" (disabled or crippled). For example, "disabled" had been changed by "physically-challenged". "blind" by "visually-challenged", etc. Unfortunately, the active use of this prefix has led to the appearance of unintelligent expressions, such as: 
"metabolically challenged" (having undergone final discomfort) - dead, "follicularly challenged"-bald, etc.

Age discrimination is defined by the term "ageism" (discrimination against the elderly). The use of euphemisms most often refers to respect for the elderly. Instead of the usual but inappropriate word "old", you will probably find such expressions as "third age person", "senior citizen". In most cases, age discrimination occurs when applying for a job, as both too young and elderly candidates are screened out. Ageism deals with stereotypes and biases.

In addition to the familiar types of discrimination, the United States also highlighted property discrimination. When there is a need to describe the financial status of the person necessary to avoid expressions that evoke unpleasant associations. "Poor" is replaced by the more correct economically "exploited", "socially weak'. Also, when talking about a person's difficult financial situation, it is advisable to use differently advantaged various names of air tickets: "economy class flight", "business class" and "first-class flights" are also an example of politically correct vocabulary.

But on the contrary of PC US traditions, the current president Donald Trump certainly stands out for his expressive and non-PC language. [7].

The authors analyzed 30 sources containing D. Trump's public statements. One of the most frequently used adjectives by Donald Trump is "smart", i.e. quick-witted. Trump uses this word when talking about the foreign policy of other countries [8]. As you can see, $\mathrm{Mr}$ Trump uses the technique of synonymous condensation in his speeches, i.e. opposition, the politically incorrect message that Americans are better than others. The following politically incorrect sayings can be found in open sources and concern the personalities of Megyn Kelly, George Bush and Jon Stewart. Trump uses politically incorrect language, considering his colleagues "dummies" (dummy, bimbo, dopey)[9].

Follow to Trump's statements is obvious that America has several detractors who "disrespect", steal", "ruin" and "mock" "the country. These words contain strongly negative connotation. Against this background, Trump is a "good politician" who will be able to establish the situation in the country and will bring it out of the economic crisis and defend the rights of American people. In addition to the adjective smart, the phrase "best people" and the synonymous expressions "the smartest guys", "brilliant people"," brilliant minds" are constantly found in Trump's speech. "The best people (minds)" will lead America when it comes to forming the President's Cabinet, competing economically with other States, or destroying ISIS. At the same time, Trump himself ranks in the category of "best people", promising to provide the country to the crisis in unemployment: "Additionally, I would be the best jobs president that God ever created".

Also, Donald Trump uses PC incorrect statements while talking about the construction of the Great Wall between the US and Mexico to stop the flow of illegal immigrants in the United States as well as concerns the idea of global warming was invented and implemented by the Chinese to destabilize the US economy and promises to erase Muslims terrorism from the Earth.[10]

\section{Conclusion}

According to the study, we can confidently state that more than most of Donald Trump's public speeches (over 80\%) have a PC discourse and more than half of them contain politically incorrect vocabulary while around quarter of them sound more or less neutral.

Based on the data analysis, we can conclude that a former political figure Donald Trump used to be a politically incorrect head of the state, as evidenced by the phrase from his speech, in which he pointed that he hadn't got any time for PC as well the country he used to govern [11]. 
But political correctness, designed to eliminate insults to various social groups, is beginning to lose its original meaning. The lack of measures and the stamping of politically correct statements provokes the substitution of the initial message and the creation of ridiculous situations. Political correctness or "radical politeness" affects the language and it is still the most important way of information exchange even if it is sometimes interpreted in a wrong way [12].

\section{Acknowledgements}

This work was supported by the Russian Foundation for Basic Research, grants No. 15-3410488 and 17-34-10303.

This paper was financially supported by the Russian Foundation for Basic Research, grant No. 20-012-22046.

\section{References}

1. Z.D. Popova Z. D., Introduction to cognitive linguistics. Izvatel'stvo Kuzbass University - Izdat, (2005) (in Russ.)

2. T.V. Yudina,Diskursivnoe prostranstvo politicheskoj rechi. Aktual'nye problemy teorii kommunikacii.Izdatel'stvo St.Peter.gos.ped.unta (2004) (in Russ)

3. L.A. Tyukina L. A., V.N. Babayan. Strukturno-kompozicionnyj analiz bytovogo anekdota na nemeckom, anglijskom i russkom yazykah kak obekta yumoristicheskogo dialogicheskogo diskursa.Izdatel'strvo Voronezh(2020) (in Russ)

4. V.N. Babayan,S.L. Kruglova. Tekst i diskurs.Izdatel'stvo Yaroslavl gos.ped.un-ta (2002) (in Russ)

5. V.N. Babayan. Diskursivnoe prostranstvo terciarnoj rechi. diss. d. filol. n. -(2009) (in Russ)

6. K.A. Melnikova., D.E. Govorukhin Politkorrektnost' kak sociokul'turnoe yavlenie v sovremennom anglijskom yazyke.Izdatel'stvo Yaroslavl gos.tech.un-ta (2020) (in Russ)

7. Debaty kandidatov v vrezidenty USA(2020) URL: https://www.kommersant.ru/doc/4511805

8. Trump's antiglobalism (2020) URL: https://www.facebook.com/ DonaldTrump/ ?hc_ref=ARR1NF8nC1rN_ADtFDGeCwta0gm_02bpz4ldsJ-C2WD5e-3 Go_ $\mathrm{X} 4$ fiwlELIRzu5g6dI\&fref $=\mathrm{nf} \& \_\mathrm{tn} \_=\mathrm{kC}-\mathrm{R}$

9. Promises made. Promises broken. Trump's failure URL: www. keepamericagreat. com

10. D.Trump's Twitter URL: Ошибка! Недопустимый объект гиперссылки. 
11. M.A. Beardy, «The word's worth», The Times (2018)

12. Comments. Wisegeek URL:https://www.wisegeek.com/what-is-positivediscrimination.htm (2020) 